\title{
The Status Quo and Cause Analysis of Hidden Discrimination Under the Employment Protection Policy for Women__ Based on the Perspective of Social Gender Theory
}

\author{
LifengLu ${ }^{1, *}$ YifenDu $^{2}$ \\ ${ }^{1,2}$ Institute of political science and law, University of Jinan, Jinan, Shandong 250022, China \\ *Corresponding Author Email: 1926918392@qq.com
}

\begin{abstract}
With the development of economy and the progress of social civilization, women gradually abandon the traditional concept of "men dominate the outside, women dominate the inside", and increase their social participation through employment in society. At the same time, the government In order to encourage female employment, the department has also introduced a series of female employment protection policies. By consulting the data from the 2016 and 2018 survey reports on the status of women's occupations in China and the data from the China Population and Employment Statistics Yearbook, this article uses descriptive statistical analysis methods to conclude that the introduction and continuous improvement of these women's employment protection policies have been made to a certain extent. The above changes the explicit discrimination that companies and other employers directly reject women's employment based on gender. However, companies and other employers still have hidden discrimination against women's employment, which is manifested in unequal employment opportunities, gender differentiation in the employment field, and occupations. Obstacles to promotion. Regarding the hidden discrimination that these women have in employment, we use relevant data to analyze the reasons behind it from the social, corporate, and female personal perspectives.
\end{abstract}

Keywords: Gender, Female employment protection policy, invisible discrimination

\section{CONCEPT DEFINITION}

\subsection{Social Gender}

The term "social gender" was first proposed by the American anthropologist Gail Lubin, and the main purpose of the proposal was to explain the identification of one's own gender in the living environment of people. It belongs to the social attributes of living beings and is different from the natural attributes of living beings. Subsequently, this concept was widely promoted in the feminist movement in the 1960s. They hoped to awaken women's feminist consciousness in this way, thereby changing the status quo of the patriarchal society and fighting for the legitimate rights of women themselves. The discussion of gender in this article is to explain the gender division of labor. The so-called gender division of labor, sociologist Parsons pointed out that gender division of labor is gender role division of labor-men play the role of family economic support and focus on career development; and Women are given the role of family caregivers and have to dedicate themselves to their husbands and children [1].

\subsection{Invisible Discrimination}

Concealed discrimination is relative to explicit discrimination. The so-called explicit discrimination means that companies and other employers will use gender and race as criteria in their recruitment announcements to decide whether to admit recruiters. And this article is based on the perspective of gender theory to discuss the status of invisible discrimination under the employment protection policy for women. Therefore, invisible discrimination is defined as the unequal employment opportunities provided by employers and other employers to men and women in the recruitment process; corporate companies, etc. Employers will focus on recruiting male professionals in a certain employment field based on the characteristics of 
women, resulting in gender differentiation between women and men in the employment field. Finally, from the perspective of the promotion policies of employers such as companies, women and men are Differences in promotion opportunities.

\subsection{Employment protection policy for women}

The formulation of women's employment protection policies refers to the adoption of legislation and various social policy measures to ensure that women and men enjoy equal employment rights and opportunities [2]. The female employment protection policy can be traced back to the 1922 China Working Women's Protection Policy, and the most recent announcement was the "Notice on Recruitment to Promote the Employment of Women" jointly issued by the nine major departments in February 2019. The notice clearly stipulates that "sex discrimination in employment in the recruitment process is prohibited in accordance with the law. All kinds of employers and human resource service agencies shall not limit gender in the process of drafting recruitment plans, publishing recruitment information, and recruiting personnel (the national regulations are taboos for female employees). (Except for work scope, etc.) or gender priority, do not restrict women's job hunting or refusal to hire women on the grounds of gender, do not inquire about women's marriage and childbirth, do not use pregnancy tests as entry physical examination items, do not use restriction of births as employment conditions, and no difference Increasing employment standards for women." In addition, Article 13 of the Labor Law of the People's Republic of China stipulates that women and men have equal employment rights. When hiring employees, they should not refuse to hire women on the grounds of gender, except for jobs or positions that are not suitable for women as stipulated by the state.

\section{THE STATUS QUO OF INVISIBLE DISCRIMINATION UNDER THE FEMALE EMPLOYMENT PROTECTION POLICY}

The 2015 Global Gender Gap Report showed that Chinese women ranked first in the world in terms of employment, and the ratio of women to men's employment reached 1.07. This data shows that women's social activities and economic participation in our country are getting higher and higher. The increase in women's social participation has led the government to promulgate some employment protection policies that help women's development, but employers still have hidden discrimination against women in employment.

\subsection{Unequal Employment Opportunities}

Although the constitution stipulates and requires employers to treat men and women equally. However, the traditional concept of "men are strong and women are weak" still has an inscrutable impact on our employers[3]. First of all, women are often asked at job fairs, "Are you married?" "Will you consider having children in recent years?" and so on. On the surface, these questions are just asking about your basic situation. In fact, these questions are based on women's answers to further deprive women and men of equal employment opportunities. Secondly, some employers seem to have uniform educational requirements for men and women in their recruitment brochures, but in practice they will reject female employees due to insufficient educational background. This inconsistent operation has also contributed to the inequality of employment opportunities for men and women to a certain extent. According to a survey report on Chinese professional women published by Zhaopin.com in $2016,38 \%$ of the women interviewed indicated that they had suffered gender discrimination in job hunting.

\subsection{Gender Differentiation In The Field Of Employment}

According to the data in the China Women's Occupation Report published by Zhaopin Recruitment in 2016, we define the field of employment as two aspects: the field of employment and job title and the angle of job title. First of all, in the field of employment jobs, women are mainly engaged in business related to customers and finances. Among them, administration/logistics/secretary, sales, finance/accounting/auditing, and human resources are the positions that women take the most, while men are the positions. They are concentrated in technical, production and processing positions. In short, the advantages of men's positions are mainly concentrated in technical positions.Secondly, this gender differentiation is also reflected in the occupational hierarchy. Female employees mostly play the roles of ordinary employees and basic-level managers, while the middle-level and high-level managers in companies are mostly men[4].

\subsection{Imbalanced promotion opportunities}

Promotion is the goal that every professional employee has been pursuing, and to a certain extent it also fully reflects the gender difference[4]. According to the 2016 China Women's Workplace Survey, 64\% of people agree that men are more likely to be promoted in the workplace, and $71 \%$ agree that the workplace ceiling phenomenon is more serious among women. The socalled workplace ceiling means that after reaching a certain level in the workplace, both the promotion channel and the promotion space become smaller and smaller. In response to the gender differences in promotion, the 2018 Chinese Women Survey Report further investigated the factors hindering women's promotion by issuing relevant questionnaires. The survey data shows that in addition to "limited promotion opportunities provided by the company", "personal 
ability and experience" The two objective factors of "insufficiency" have a certain hindering effect on both men and women. The biggest obstacle that women face in terms of promotion is "in the stage of marriage and childbirth, passively losing promotion opportunities", while men are in the workplace. The right factors that hinder promotion are some bad phenomena in the workplace.

\section{ANALYSIS OF THE FACTORS OF INVISIBLE DISCRIMINATION UNDER THE FEMALE EMPLOYMENT PROTECTION POLICY}

Women's employment policy aims to promote women's employment and development[5]. However, traditional social concepts, the nature of enterprises seeking to maximize benefits, and even due to women's personal characteristics, including women's physical and psychological tolerance, are less than men's and so on. All have led to the problem of invisible discrimination against women in employment by enterprise employers.

\subsection{Social Factors}

Traditional concepts in society have also led to invisible discrimination of women in the job market to a certain extent[6]. First of all, it can be seen from the theory of gender that compared with men, women are often given more family roles than they are given to society. In other words, women tend to pay more attention to the family than men. This phenomenon can also be derived from Table 1. Obviously, it is easy to see that women's family time is higher than their working hours. That is to say, for women, while ensuring the same length of work per day, women always need to spend more time to take care of the family and work. Engaging in housework also reflects that women tend to do more things than men in a day. In the long run, women will suffer more and more physical and psychological pressures, and women cannot invest as much in work as men. The energy has led to the slow career development of women.

Table 1. Comparison of working hours and family time

\begin{tabular}{cccc}
\hline & female & male & $\begin{array}{c}\text { Gap (proportion } \\
\text { of males higher } \\
\text { than females) }\end{array}$ \\
\hline $\begin{array}{c}\text { Working hours } \\
\text { per week }\end{array}$ & 47.0 & 51.3 & $9 \%$ \\
$\begin{array}{c}\text { Time spent in } \\
\text { the family every } \\
\text { day }\end{array}$ & 2.0 & 1.7 & $-15 \%$ \\
& & & \\
\hline
\end{tabular}

Data source: 2018 China Women's Workplace Survey Report

\subsection{Corporate Factors}

This article defines an enterprise as a private enterprise here. The fundamental purpose of these private enterprise employers is to pursue profit, and their goal is to maximize profits[6]. Therefore, these private enterprises will try to reduce costs as much as possible, both in terms of recruitment and operations. Most private enterprises will think that not only are women inferior to men in terms of physical fitness, but because women also have to bear the social responsibility of reproducing offspring, women's ability to work will be greatly reduced. In addition, the national labor law also stipulates the rights that women enjoy during illness, childbirth, and pregnancy, requiring enterprise employers to provide certain benefits to women during illness, childbirth, and pregnancy. However, companies often choose to deliberately choose to save costs. Ignore or avoid deliberately. The benefits that women enjoy in companies are not optimistic. According to the survey data of Zhaolian Recruitment on the status quo of female workplaces in 2016 , only $16 \%$ of the people said that the company has special benefits for women, while up to $65.6 \%$ said that the company does not have special benefits for female employees.

\subsection{Female Personal Factors}

In recent years, although women's right to education has been continuously valued, overall, the proportion of women without education is much higher than that of men. According to the female education data released by the China Population and Employment Statistics Yearbook, women's education level is relatively low, and the proportion of women with a college degree or above is only $19.9 \%$. Most of the employed women's education level is junior high school and the following. Women's low education level makes women less competitive in the market than men, which in turn leads to the fact that the market tends to prefer men for employment, which results in women's disadvantaged position in employment[7]. Second, rather than equating men with rationality, women are often associated with sensibility. Women are emotionally sensitive, and they are especially prone to negative emotions such as anxiety when they feel pressure. These negative emotions will further affect women's working conditions and ultimately affect the profit output of enterprises.

\section{CONCLUSION}

China's labor protection policy framework for women was first formed in 1922. Since then, China has successively promulgated the "Working Protection Regulations for Women Workers" (1956), the "Provisions on the Labor Protection of Women Workers" (1988), and the "Prohibited Labor Scope for Female Workers". Regulations (1990) and Special Labor Protection 
Regulations for Female Workers (2012), etc. The most recent female employment protection policy is the "Notice on Recruitment Behavior to Promote Women's Employment" jointly issued by the nine major departments in 2019. In summary, my country has been paying attention to promoting women's career development and protecting women's employment rights and formulating corresponding policies to protect women's rights[8]. However, the implementation of these policies to protect women's rights in many employers, such as companies, is often not in place. Many private companies tend to avoid recruiting or hiring women in order to maximize profits and minimize costs, so women lose equal employment opportunities or promotion opportunities with men. Therefore, my country should introduce relevant legal standards to further regulate the recruitment behavior of private enterprises and other employers, and try to make the recruitment process more open and transparent; secondly, private enterprises should also take into account social benefits while pursuing the maximization of benefits, and protect women's employment. Rights; Finally, from the perspective of female individuals, female individuals should actively participate in relevant vocational training to increase their competitiveness in the market.

\section{ACKNOWLEDGMENT}

This work was financially supported by Shandong Provincial Social Science Planning Research Project .and this article is the phased result of the Shandong Provincial Social Science Planning Research Project (Project Number: 20CSHJ01).

\section{REFERENCES}

[1] Parsons, Talcott.AGE AND SEX IN THE SOCIAL STRUCTUREOF THE UNITED STATES.[J].American Sociological Review.1942,Vol.7(No.5):604-616. DOI:

https://doi.org/10.2307/2085686

[2] Wang Yiping. Social Gender Theory: A New Perspective on Gender Equality[J]. Collection of Dongyue, 2001, (04): 59-61. DOI: 10.3969/j.issn.1003-8353.2001.04.017.

[3] Wang Zhi, Deng Man. Analysis of the current situation and countermeasures of gender discrimination in female employment in my country [J]. Journal of Chongqing Electronic Engineering Vocational College, 2015, 24(06): 70-74. DOI: 10.13887/j.cnki.jccee.2015 (6) .18

[4] Peng Xiaoxiao. Analysis of the reasons affecting women's employment in my country [J]. Chinese and Foreign Entrepreneurs, 2013, (15): 214-215. DOI: $10.3969 / \mathrm{j}$. issn.1000-8772.2013.16.107.
[5] Zhou Aiping, Kong Haie. The evolution of social policies for the development of Chinese women[J]. Journal of China Women's University, 2012, 25(03): 67-71. DOI: 1007-3698 (2012) 03-0067-05

[6] Li Chengpeng. The problem of female employment discrimination in my country and its solutions[J]. Hebei Enterprise, 2020, (09): 123-124. DOI: 10.3969/j.issn.1008-1968.2020.09.051.

[7] Hao Ran. Analysis of the influencing factors of female employment in my country [J]. Shandong Social Sciences, 2009, (01): 114-117. DOI: 10.3969/j.issn.1007-3698.2012.03.012

[8] Li Hong. Research on Social Policy from the Perspective of Social Gender [J]. Journal of China Women's University, 2008, (02): 46-51. DOI: 10.3969/j.issn.1007-3698.2008.02.008. 